\title{
Risk perception regarding HIV AIDS of wives whose husbands are staying away from them, in an Urban Slum area of Mumbai, INDIA
}

\author{
Chavada V K ${ }^{1}$, Rajeshkumar Konduru ${ }^{2}$, Panigrahi K C ${ }^{3}$ S Sankarnarayanan ${ }^{4}$ \\ ${ }^{I}$ (Associate Professor, Dept of Community Medicine, Indira Gandhi Medical College \& Research Institute \\ Pondicherry, India) \\ ${ }^{2}$ (Assistant Professor, Department of Community Medicine P.E.S Institute of Medical Sciences and Research \\ Dr.N.T.R University Of Health Sciences Kuppam, India) \\ ${ }^{3}$ (Professor and Head, Dept of Community Medicine, Indira Gandhi Medical College \& Research Institute \\ Pondicherry, India) \\ ${ }^{4}$ (Professor, Dept of Preventive and Social Medicine, T N Medical College, Nair Ch Hospital, Mumbai, India)
}

\begin{abstract}
Aim : Assessment of Risk perception regarding HIV AIDS of wives whose husbands are staying away from them OBJECTIVES: 1. To assess the risk perceptions of wives regarding their husbands' extramarital affairs while staying away from them, with regards to HIV/AIDS 2. To find out effect of various socio-economic factors on their perceptions. METHODS: Cross-sectional study of Sample of around 60 married females, whose husbands are staying away from them, selected by Snow ball sampling technique and using Central limit theorem in the reproductive age group of 18 to 45 years, were included. RESULTS: $88 \%$ of wives felt that due to their absence and separation there is a possibility of their husbands' involvement in extramarital affairs. Also $82 \%$ of the wives even were ready to accept if and when such affair comes to light. $80 \%$ of the females were aware of HIV/AIDS and only $47 \%$ out of them knew about the risk of getting infection from their husbands. CONCLUSIONS: Most of the females are ready to accept the chances of development of husband's extramarital affair due to separation but still are willing to continue with the relation inspite and despite of the knowledge about HIV/AIDS. And factors such as - Future of children, financial security, she not earning are forcing her to continue with the relationship.
\end{abstract}

Keywords: Extra marital affairs, risk perception regarding HIV/AIDS

Corresponding Author: Dr Chavada V K, Associate Professor, Dept of Community Medicine, Indira Gandhi Medical College \& Research Institute Pondicherry, India

\section{INTRODUCTION}

India has witnessed industrialization over last few decades to a large extent leading to local, regional as well as international migration as a result of globalization. Migration of economically productive sections of the population is a common phenomenon all over India ${ }^{1 .}$ The traditional family system is undergoing continuous transformation due to direct and indirect result of this migration. Apart from the multi-dimensional nature of causality of migration; it itself has multi-factorial effects on various aspects of human life, some favorable and others not. At one end when it is leading to economic growth of the state at large \& improved living conditions for individuals and families; though not equally distributed throughout all sectors of population but at the other end it definitely has a negative effect when it comes to psychosocial or behavioral aspects especially affecting the arena of health.

In this context, the urban slum of Cheetah Camp, Mumbai. is one such area which consists of population with unique dynamics which remains non-static all the time since its formation - with bidirectional flow consisting of both migrants from rural interiors of whole country and emigrants from this area going out to areas like gulf countries for better opportunities and avenues.

With special emphasis on migration of husbands to different area leading to separation from their wives makes them vulnerable and at risk. So, this study was conducted in the urban slum area of Cheetah Camp with the following objectives.

\section{AIM \& OBJECTIVES:}

I. To assess the perceptions of wives regarding their husbands' extramarital affairs while staying away from them.

II. To find out effect of various socio-economic factors on their perceptions.

III. To assess their risk perceptions with regards to HIV/AIDS. 


\section{Materials \& Methodology}

Since the issue involved was very sensitive, especially for the said community (involving majority of the Muslim population) data was collected during one-to-one interviews using semi-structured Questionnaire, after rapport building with the individual subjects. All interviews were conducted at the Urban Health Center, Shahajinagar, Trombay, Mumbai as the issue could have not been discussed in the house to house visits.

\section{SAMPLING METHOD}

Snow Ball Sampling Technique ${ }^{2}$ was used to collect the required sample size of 60 , which was priory decided to fulfill 'Central Limit Theorem' ${ }^{3}$ as two composite variable were to be measured as the outcome: one- perceptions of wives regarding husbands extramarital affairs \& two- Risk perceptions of wives regarding HIV/AIDS.

\section{INCLUSION CRITERIA}

Wives having $\mathrm{h} / \mathrm{o}$ their husband not staying with them \& willing to participate in the study. Wives in the reproductive age group of 18-45 yr. Wives whose husband are staying away since last 1 year for not less than 6 months (continuously) staying apart from her. Only residents of Cheetah Camp.

\section{QUESTIONNAIRE \& SCALE CONSTRUCTION}

Semi-structured Questionnaire was prepared which included information about following variables:-

$>$ Identification data of Subjects

$>$ Perception of wives regarding their husband's extramarital affairs.

$>$ Knowledge regarding HIV/AIDS including source of information.

$>$ Risk Perceptions of HIV/AIDS.

Likert Scale ${ }^{2}$ was used to measure the composite variables of agreement.

The data was analyzed using software (SPSS version 12.0)

VII. RESULTS \& DISCUSSION

Table 1: Descriptive Statistics:

\begin{tabular}{|l|l|l|l|}
\hline Characteristic & Mean & S.D. & S.E. \\
\hline Age & 29.996 & 9.336 & 1.112 \\
\hline No. of yrs of marriage & $\mathbf{8 . 3 1 7}$ & 4.312 & 0.557 \\
\hline Total Family members & 5.617 & 1.3 & 0.168 \\
\hline Total no. of children & 2.817 & 1.08 & 0.139 \\
\hline Yr of stay of husband away from wife & $\mathbf{4 . 1 8 3}$ & 2.446 & 0.316 \\
\hline Per Capita Income & $\mathbf{1 5 0 0 0 . 6 2 5}$ & 4760.95 & 611.57 \\
\hline Frequency of visit of husband (per yr) & 2.666 & 0.542 & 0.0699 \\
\hline Average duration of husband's stay at home (month) per yr. & 1.408 & 0.627 & 0.081 \\
\hline
\end{tabular}

Almost half of the married yrs. of life of wives was in separation from their husbands still they are bearing higher no. of children. But the separation has definitely given them higher economic benefits showing Per Capita Income over fifteen thousand rupees.

Table2: Level of Education of wives

\begin{tabular}{|l|l|l|}
\hline Level of Education of wives & Frequency & Percentage \\
\hline Illiterate & 9 & 15 \\
\hline Primary & 5 & 8.3 \\
\hline Secondary & 46 & 76.7 \\
\hline Above secondary & 0 & 0 \\
\hline Total & 60 & 100 \\
\hline
\end{tabular}

Larger proportions of the wives were literate and educated up to secondary school.

Table 3: Perceptions of wives regarding husband's extramarital affairs

\begin{tabular}{|l|l|l|l|l|l|}
\hline Questions regarding perceptions & SA & A & Can't say & DA & SDA \\
\hline $\begin{array}{l}\text { Possibility of husband's extramarital affair due to } \\
\text { wife's absence (making the husbands vulnerable) }\end{array}$ & $0 \%$ & $\mathbf{8 8 . 3} \%$ & $10 \%$ & $1.7 \%$ & $0 \%$ \\
\hline $\begin{array}{l}\text { Acceptance of husband's extramarital affair, in case it } \\
\text { comes to light }\end{array}$ & $\mathbf{1 . 7} \%$ & $\mathbf{8 0} \%$ & $16.7 \%$ & $1.7 \%$ & $0 \%$ \\
\hline
\end{tabular}

(SA - Strongly Agree, A - Agree, DA - Disagree, SDA -Strongly Disagree ) 
Almost $\mathbf{8 8 \%}$ of females agreed that there is possibility of their husband's extramarital affair because of their absence if it happens the reason would be their absence and separation from their husband. Surprisingly $\mathbf{8 2 \%}$ of them even were ready to accept if and when such affair comes to light. For such acceptance various reasons quoted by them are 1 . Future of children 2. Financial insecurity 3. Social insecurity and 4. She not earning are forcing her to continue relationship.

Table 4: Knowledge of wives regarding HIV/AIDS

\begin{tabular}{|l|l|l|}
\hline Knowledge of HIV/AIDS & Frequency & Percent \\
\hline Correct knowledge and source of HIV/AIDS infection & 48 & 80 \\
\hline Incorrect knowledge and source of HIV/AIDS infection & 12 & 20 \\
\hline Total & 60 & 100 \\
\hline
\end{tabular}

$80 \%$ respondents were aware about what HIV/AIDS is and what is the source of HIV/AIDS.

Table 5: Risk Perception of wives regarding HIV/AIDS

\begin{tabular}{|l|l|l|l|l|l|l|}
\hline $\begin{array}{l}\text { Risk Perception of wives regarding } \\
\text { HIV/AIDS due to } \\
\text { extramarital affair }\end{array}$ & Susband's & SA & A & Can't say & DA & SDA \\
\hline frequency & 0 & 23 & 5 & 29 & 3 \\
\hline Percentage & 0 & 38.3 & 8.3 & 48.3 & 5 \\
\hline
\end{tabular}

(SA - Strongly Agree, A - Agree, DA - Disagree, SDA -Strongly Disagree)

While $80 \%$ of the females were aware of HIV/AIDS, only $38.3 \%$ out of them knew about the risk of getting infection from their husbands.

Umesh Sharma, et $\mathrm{al}^{4}$, in his study found that, 81.4 percent of respondents had high level of knowledge on HIV/AIDS, 87.6 percent had high and moderate level of perception.

Table 6: Effect of various factors on Perceptions of wives regarding husbands extramarital affairs (Multiple Regression Analysis) Coefficients

\begin{tabular}{|l|l|l|l|l|l|}
\hline \multirow{2}{*}{ Model 1 } & \multicolumn{2}{l|}{$\begin{array}{l}\text { Unstandardized } \\
\text { Coefficients }\end{array}$} & $\begin{array}{l}\text { Standardized } \\
\text { Coefficients }\end{array}$ & \multirow{2}{*}{ Sig. } \\
\cline { 2 - 5 } & $\mathbf{B}$ & Std. Error & Beta & & 0 \\
\hline (Constant) & 11.717 & 2.061 & & 5.686 & 0 \\
\hline Cable TV & 1.529 & 0.38 & 0.419 & 4.025 & $<\mathbf{0 . 0 5}$ \\
\hline $\begin{array}{l}\text { No of years Husband } \\
\text { staying away }\end{array}$ & 0.32 & 0.072 & 0.549 & 4.454 & $<\mathbf{0 . 0 5}$ \\
\hline
\end{tabular}

Multiple Regression Analysis

\begin{tabular}{|l|l|l|l|l|l|}
\hline \multirow{2}{*}{ Model 1 } & \multicolumn{2}{|l|}{ Unstandardized Coefficients } & $\begin{array}{l}\text { Standardized } \\
\text { Coefficients }\end{array}$ & \multirow{2}{*}{ Sig. } \\
\cline { 2 - 5 } & $\mathbf{B}$ & Std. Error & Beta & & -2.019 \\
\hline (Constant) & -3.168 & 1.569 & & 0.05 \\
\hline Cable TV & 0.587 & 0.132 & 0.448 & 4.454 & $\mathbf{0 . 0 0 3}$ \\
\hline $\begin{array}{l}\text { No of years Husband } \\
\text { staying away }\end{array}$ & 0.32 & 0.072 & 0.549 & -2.648 & $\mathbf{0 . 0 1 2}$ \\
\hline occupation of husband & -0.255 & 0.096 & -0.267 & -2.915 & $\mathbf{0 . 0 0 6}$ \\
\hline Source of information & $-6.74 \mathrm{E}-02$ & 0.023 & -0.319 & 4.727 & $<\mathbf{0 . 0 5}$ \\
\hline Perceptions of females & 0.41 & 0.087 & 0.571 & & \\
\hline
\end{tabular}

Almost $70 \%$ of the variation in the Dependent Variable (i.e. Risk Perception of the wives for contracting to HIV/AIDS through their husbands) is explained by the independent variables. All the independent variables entered to predict the Risk Perception are good enough to predict dependent variable (ANOVA $\mathrm{p}<0.05) 95 \%$ females had Cable TV at home.

Presence of Cable TV at home $(\mathrm{p}=0.003)$, source of information $(\mathrm{p}=0.006)$, occupation of the husband $(p=0.012)$ and Perception of wives regarding their husbands extramarital affairs $(p<0.000)$ had maximum ability to predict the variation in the Risk Perception of the wives for contracting to HIV/AIDS through their husbands. Availability of the Cable TV at home and No. of yrs of husbands stay away from home were significantly affecting the perceptions of the wives regarding their husbands' extramarital affairs. Migration of economically productive sections of the population is a common phenomenon all over India. According to the 1993 National Sample Survey in India, $24.7 \%$ of the population had migrated, either within India, to neighboring countries or overseas. Applying this percentage to the mid-2003 population about 264 million Indians are mobile ${ }^{5}$ 
"Being mobile in itself is not a risk factor for HIV infection. It is the situations encountered and the behaviors possibly engaged in during mobility or migration that increase vulnerability and risk regarding HIV/AIDS." 1

Umesh Sharma,et al ${ }^{4}$, in his study found that regarding the sources of information, 79 percent of respondents received information about HIV/AIDS from friends/neighbors, 81.4 percent of respondents had high level of knowledge on HIV/AIDS and 87.6 percent had high and moderate level of perception.

In the current study it has been found that, $80 \%$ respondents had the knowledge of HIV/AIDS, only $38.3 \%$ respondents perceived that there can be a risk of contracting the disease from their husbands while presence of cable TV is playing the major role for their perceptions about knowledge and perception about HIV/AIDS, it can be used as a tool for imparting the knowledge regarding prevention and control of HIV/AIDS.

\section{SUMMARY \& CONCLUSIONS}

Almost $\mathbf{8 8 \%}$ of females agreed that there is possibility of their husband's extramarital affair because of their absence that is if it happens the reason would be their absence and separation from their husband.

Surprisingly $\mathbf{8 2 \%}$ of them even were ready to accept if and when such affair comes to light. While most of them $\mathbf{8 0 \%}$ had knowledge about HIV/AIDS; only half of them $\mathbf{3 8 \%}$ are actually aware of their risk of getting HIV/AIDS from their husbands. This naturally implies that these wives will be at risk and the reason being lack of minimal scientific knowledge about HIV/AIDS including the modes of transmission and its prevention.

Presence of Cable TV $(p<0.000)$ at home and source of information $(p=0.003)$ have the maximum ability to predict the Knowledge of HIV/AIDS of the wives.

Presence of Cable TV at home $(p=0.003)$, source of information $(p=0.006)$, occupation of the husband $(p=0.012)$ and Perception of wives regarding their husbands extramarital affairs $(p<0.000)$ had maximum ability to predict the variation in the Risk Perception of the wives for contracting to HIV/AIDS through their husbands.

Cable TV at home is playing the major role for their perceptions about HIV/AIDS, hence it can be used as a tool for imparting the knowledge regarding prevention and control of HIV/AIDS.

Most of the females are ready to accept the chances of development of husband's extramarital affair due to separation but still are willing to continue with the relation. And factors such as -

1. Future of children 2.Financial insecurity 3. Social insecurity and 4. She not earning are forcing her to continue relationship.

\section{RECOMMENDATIONS}

1. Health Education: Imparting the knowledge regarding prevention and control of HIV/AIDS to the respondents

As there was inadequate knowledge leading to inability to assess the risk of HIV/AIDS for the respondents and since the perceptions of respondents regarding their husbands' extramarital affairs will always have the cultural context, still factors like cable TV at home has the significant impact on these perceptions. This implies the need of molding the Information, Education and Communication (IEC) activities for HIV/AIDS prevention in such a way that it fits the cultural context as well as reaches through the same media which has maximum role in formation of their perceptions about their husbands' extramarital affairs.

\section{Empowering women:}

Imparting health education regarding HIV/AIDS through cable TV which is the well accepted tool will empower females to negotiate with their husbands in subsequent relation and decisions in focus of HIV/AIDS threat for them individually as well as for the family.

\section{Increasing the scope of vocational training:}

Vocational training centers exclusively for females should be sufficiently and efficiently increased so that females can become self sufficient to earn their livelihood and ultimately should not have to depend on husband's income and can have an upper hand in relationship.

\section{References}

[1]. Population reference Bureau (2003) '2003 Data Sheet Highlights: Using Global Population Projections', Data Sheet

[2]. Text book of Survey Methods in Community Medicine by J H Abramson, Fifth Edition, 2002 , Churchill Livingstone Publications

[3]. APN Nurses' Manual of research methodology, Third Edition, 1996, Century Publications

[4]. Umesh Sharma, Study of HIV/AIDS preventive behavior of women attending antenatal clinic in Ratchvithi hospital, Bangkok Metropolitan, Thailand, 1999.

[5]. UNAIDS (2001) 'Population Mobility and AIDS', Technical Update, February, p.5 